\title{
Locally Owned Bank Concentration and Business Start-Ups and Closures in U.S. Metropolitan, Micropolitan, and Rural Counties from 1980-2010*
}

\author{
Craig Wesley Carpenter, ${ }^{\mathrm{a}, \mathrm{b}}$ F. Carson Mencken, ${ }^{\mathrm{c}}$ Charles M. Tolbert, ${ }^{\mathrm{c}}$ \\ and Michael Lotspeich ${ }^{\mathrm{c}}$ \\ ${ }^{a}$ Department of Agricultural Economics, Texas A\&M University, USA \\ ${ }^{b}$ MSU Extension, Michigan State University, USA \\ ${ }^{c}$ Department of Sociology, Baylor University, USA
}

\begin{abstract}
Access to financial capital is vital for the sustainability of the local business sector. Recent research on the restructuring of the financial industry from local owned banks to interstate conglomerates has raised questions about the impact on local economies, especially in rural areas. We examine the impact of bank ownership concentration on business formations, continuations, and deaths in metropolitan, micropolitan, and rural non-core U.S. counties. Using limited-access Census data, we find that local bank concentration is positively related to business births and deaths, or churn, in rural counties, but the opposite effects occur in metropolitan areas. We demonstrate robustness to several specifications and spatial spillover effects.
\end{abstract}

Keywords: financing, loans, small business, local banks

JEL Codes: G21, L26, R51

\footnotetext{
${ }^{*}$ This line of research was supported, in part, by the Agriculture and Food Research Initiative of the National Institute of Food and Agriculture, grants 2011-67023-30072, 2017-67023-26242, and 2018-6800627641. Portions of this work were carried out in the Texas Federal Statistical Research Data Center. Any opinions and conclusions expressed herein are those of the authors and do not necessarily represent the views of the U.S. Census Bureau. All results have been reviewed to ensure that no confidential information is disclosed.

Craig Wesley Carpenter is an Assistant Professor and Extension Specialist at Texas AM University, College Station, TX 77843, and an Extension Specialist at Michigan State University, East Lansing, MI 48824. F. Carson Mencken and Charles M. Tolbert are Professors at Baylor University, Waco, TX 76798. Michael Lotspeich is a PhD Candidate at Baylor University, Waco, TX 76798. Corresponding Author: Craig Wesley Carpenter, Email: ccarpenter@tamu.edu
} 


\section{INTRODUCTION}

In this paper, we explore the effects of bank consolidation on local U.S. rural economies by estimating a measure of locally-owned bank concentration on the rate of county business start-ups and closures. Starting and sustaining a business often requires significant financial backing, especially for individuals who depend on the business as a primary source of income. For large business ventures there are many potential financing options, such as publicly traded stock, venture capital/private equity, and loans from large financial corporations (see Erel, 2011).

In rural communities, local business ventures are typically smaller, with fewer employees (Walzer et al., 2007; DeYoung et al., 2012). Such businesses do not typically attract the attention of large venture capital firms (Mencken and Tolbert, 2016). These smaller businesses rely on multiple sources of financing, including personal savings, small business loans from banks, credit lines, and even money from friends and family (Bird and Sapp, 2004; Craig et al., 2007; Valdez, 2011). Moreover, Mencken and Tolbert $(2016,2018)$ show that banks are a more relied-upon form of start-up and expansion capital for business owners in non-metropolitan economies, compared to similar businesses in metropolitan economies.

The patterns of mergers and acquisitions in the U.S. financial sector since the 1980s have led some scholars to be concerned about disadvantages for businesses that attempt to start and/or operate in rural locations (see Tolbert et al., 2014; Flora et al., 2015; Mencken and Tolbert, 2018). Historically, local banks and local businesses formed symbiotic relationships, which often included practices of 'relationship' lending. Rural economies were no exception (Dudley, 1996; DeYoung et al., 2012; Gilbert and Wheelock, 2013). The U.S. pattern of bank mergers and acquisitions over the last 35 years has meant a decline in the number of bank firms and an increase in the number of bank establishments. ${ }^{1}$ During this same time frame there has been a significant decline in the percentage of locally owned banks in all U.S. counties (Tolbert et al., 2014).

The concern is that the loss of independent local banks has led to a small business credit constraint in non-metropolitan economies. As we show below, studies on the implications of financial sector restructuring suggest that the primary effects are short-term interruptions in cash flow to the small business sector. However, these conclusions are based mostly on national, state, and/or urban (MSA) level analyses. ${ }^{2}$ We concur with previous research (DeYoung et al., 2012; Gilbert and Wheelock, 2013) and argue further that locally-owned financial institutions are more important for the economic vitality of rural communities than urban settings. Rural communities do not enjoy multiple banks that compete with one another with lower interest rates. The return on investments in rural communities may not be sufficient to draw significant investments from larger absentee owned banks. Also, businesses in rural economies, which are typically small, may lack the physical capital necessary to secure collateral-based loans. When it comes to securing financing, owners'

\footnotetext{
${ }^{1}$ This article follows the U.S. Census Bureau convention of using the term "establishment" to refer to a physical location or "address" where economic activity takes place, and the term "firm" to refer to a collection of one or more establishments under a common ownership structure.

${ }^{2}$ Several studies are available on the impact of interstate banking on farm and agriculture (see Briggeman et al., 2009; Kerr and Nanda, 2009; Kandilov and Kandilov, 2017).
}

(c) Southern Regional Science Association 2020. 
social capital is increasingly irrelevant even in the villages and small towns where they are well known.

We investigate the impact of financial sector restructuring in rural economies by examining the impact of the concentration of locally owned financial institutions on county business start-ups and deaths during the 1980-2010 time period. We examine these effects with non-additive/interaction models with which we differentiate the effects for metropolitan, micropolitan, and rural non-core counties separately. ${ }^{3}$ We first begin with a description of financial sector restructuring, a review of the literature and prevailing hypotheses.

\section{FINANCIAL SECTOR RESTRUCTURING}

Since 1980, there has been a flurry of mergers and acquisitions among financial institutions. Between 1984 and 2016, the number of U.S. Federal Deposit Insurance Corporation (FDIC) reported bank firms declined from 14,483 to 5,737 while the number of banking establishments increased from 42,404 to $80,227.4$ There are fewer multi-site bank firms, but significantly more branches/establishments of large banks dispersed throughout the U.S. This merger and acquisition pattern was aided in part by the implementation of the 1994 Riegle-Neal Interstate Banking Act, and also improvements in communication and information processing technologies (Whaling, 1996; DeYoung et al., 2004; Cetorelli and Strahan, 2006). Some mergers were the result of bank failures and the S\&L crises of the late 1980s. There was also another uptick in mergers during the Great Recession following 2008 (Rice and Rose, 2016). In any given year, however, the vast majority of bank mergers were unrestricted acquisitions (i.e. those involving non-failing banks).

Despite federal oversight from the Community Reinvestment Act, there is concern that a proliferation of establishments at the local level - many of which were former independent and regional banks that serviced local businesses - will lead to a loss of deposits in local institutions (Devaney and Weber, 1995; Berger and Udell, 1995; Collender and Frizell, 2002; Collender and Shaffer, 2003, 2009; Berger and Black, 2011; Boot, 2011). In 2014, over half of all branch establishments in the U.S. were owned by a bank or bank holding company in another state. The consolidation is also reflected in the deposits controlled by the largest national banks. In 2017, the three largest banks in the U.S (Bank of American, J.P. Morgan Chase, and Wells Fargo) controlled 45.7 percent of all deposits in the nation's 50 largest banks. In 1994, the three largest banks controlled only 16 percent of the all deposits in the nation's 50 largest banks. ${ }^{5}$

This consolidation correlates with a reduction in the proportion of locally owned or community banks. Tolbert et al. (2014) show that the percentage of locally owned banks in metropolitan, micropolitan, and rural non-core counties decreased significantly over time. By local we mean that the bank exists in a single location or is part of a local enterprise that

\footnotetext{
${ }^{3}$ The U.S. Office of Management and Budget delineates metropolitan and micropolitan statistical areas according to published standards that are applied to U.S. Census Bureau data. Metropolitan counties must have an urbanized area of 50,000 or more inhabitants. Micropolitan counties must have at least one urban cluster of at least 10,000 but less than 50,000 population. All other counties are considered non-core.

${ }^{4}$ Downloaded from http://www.fdic.gov on January 9, 2018.

${ }^{5}$ Downloaded from http://www.fdic.gov on January 26, 2018.
}

(C)Southern Regional Science Association 2020. 
Figure 1: Percent Independent Local Banks (1976-2015)

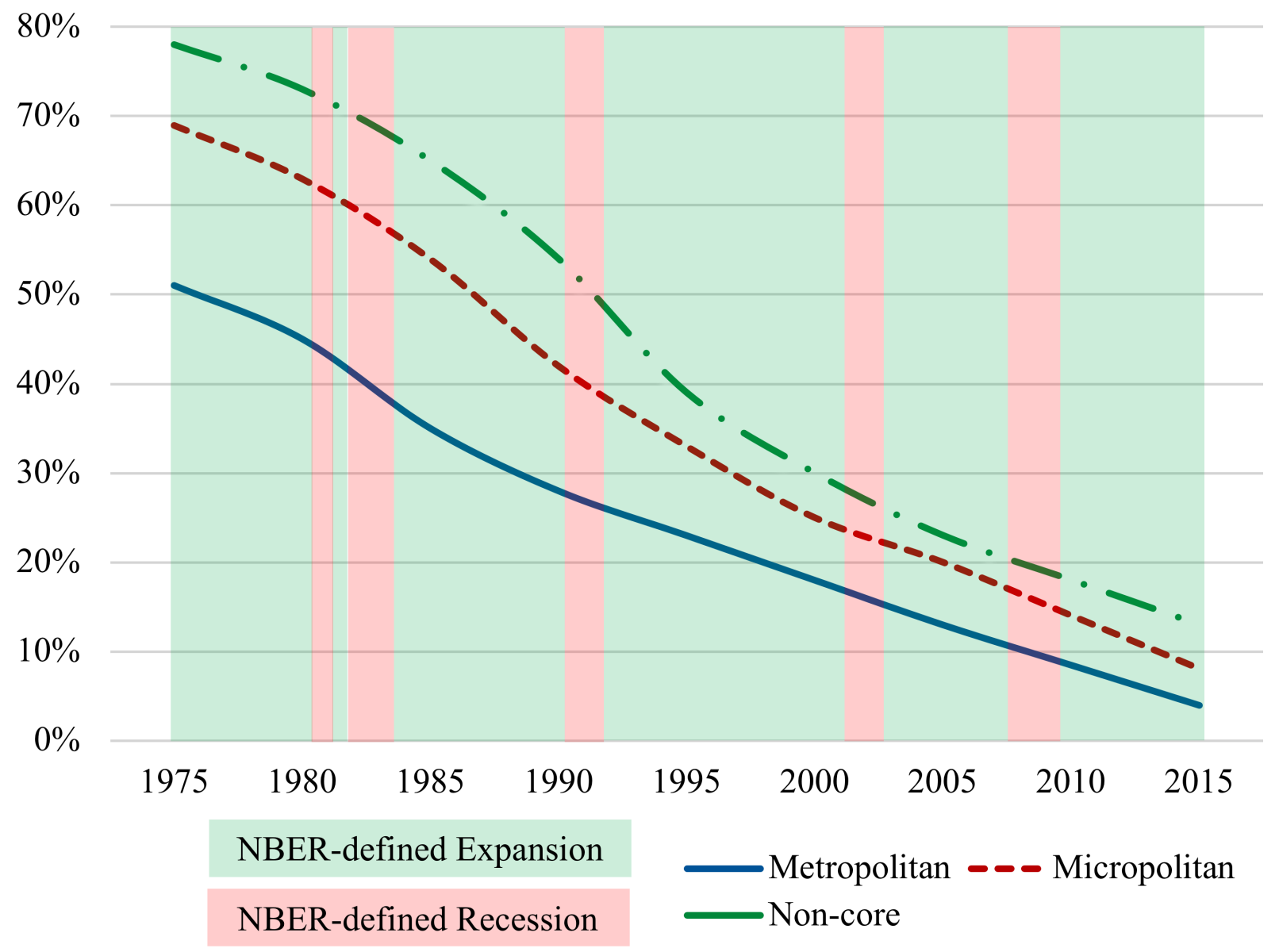

operates within a single county. Figure 1 displays this trend, and highlights how, though the trend exists across counties of all ruralities, more rural non-core counties experienced a larger decline. In 1976, 80 percent of financial institutions in rural non-core counties were independent local banks. By 2010, less than 25 percent of financial establishments in rural non-core counties were independent local banks. There was a contemporaneous decline in the share of business owners obtaining a conventional start-up business loan from a bank, declining steadily over time from 12 percent in the 1980s to 6 percent in the 2000s in metropolitan areas and 21 percent to 12 percent in non-metropolitan areas. ${ }^{6}$ Mencken and Tolbert (2018) provide more evidence of the relationship, showing that - even while controlling for the wide variety of business, business owner, and regional factors - the greater the proportion of local banks in non-metropolitan areas, the greater the odds that an owners uses a conventional business loan to help start a new business or expand an existing business.

\footnotetext{
${ }^{6}$ Percents are authors' calculations using U.S. Census Bureau Characteristics of Business Owners survey and Survey of Business Owners.
}

(c) Southern Regional Science Association 2020. 


\section{FINANCIAL SECTOR RESTRUCTURING AND LENDING}

A body of research on the effects of bank consolidation has concluded that any negative consequences were short-term because interstate banking created structural changes in the banking sector in the form of fewer credit constraints. Much of this research has concluded that interstate banking and bank firm consolidation has a) reduced monopolies of inefficient local banks, b) increased efficiency throughout the banking sector, and c) lowered the costs of loans for borrowers (Petersen and Rajan, 1994; Jayaratne and Strahan, 1998; Kerr and Nanda, 2009; Rice and Strahan, 2010). Proponents of the market concentration perspective argue that consolidation has been good for small and local business lending, bringing larger financial institutions into under-served markets, with more stable loan rates for small businesses (Markley and Shaffer, 1993; Vera and Onji, 2010; Erel, 2011). Historically, small and local banks were in symbiotic relationships with local, small businesses (Collender and Frizell, 2002; Boot, 2011). However, economic downturns could severely impact local banking. ${ }^{7}$ For example, the farm value bubble burst in the early 1980 s led to farm bank failures at rates not seen since the Dustbowl (Calomiris et al., 1986). ${ }^{8}$

During economic contractions, small businesses borrow less money, affecting the profitability of small, local banks. Smaller banks suffer more when small businesses cannot pay back loans or when these businesses cannot afford to borrow money. Poor bank health means less lending (Peek and Rosengren, 1995; Rice and Rose, 2016). During periods in which there is a reduction in the supply of loans, small businesses have less capital with which to work. Fewer investments and improvements are made, making the businesses less profitable and credit worthy. Moreover, the unavailability of cheap external credit can lead to constrained regional employment growth (Boustanifar, 2014). A concentration of large, multi-market banks in local markets reduces this possibility.

Kashyap and Stein (2000) conclude that interstate banking has been good for small businesses because it synchronized business cycles at the state level. Reductions in the supply of loans or increases in non-loan payments in one state can be offset by stronger performance in other states. They further argue that any decline in small business lending that resulted from bank consolidation is, at most, a short-term effect. Others propose that the technological expertise that larger banks brought to banking in general (namely credit scoring software) has reduced the costs of processing loans and information seeking (Strahan and Weston, 1998; Berger et al., 2011). This has diminished the role of relationship lending and credit rationing for unsecured loans.

Consolidation and market concentration can lead to market monopolies, which can be advantageous for small businesses. In highly competitive banking markets, there is less profit to split among many firms, which means fewer loans for small businesses and especially start-ups (Francis et al., 2008). Consolidation, however, increases market concentration and

\footnotetext{
${ }^{7}$ Rice and Rose (2016) note that in 2009 the Great Recession led to 139 bank closures and an additional 700 banks placed on the FDIC 'watch list.' Those banks with greater exposure due to holding preferred stock in Fannie Mae and Freddie Mac were most at risk.

${ }^{8}$ The farm value bubble crisis caused the failure of 300 rural farm banks during the 1980s. See "Good times for ag: Will they last?" by Bert Ely American Bankers Association. ABA Banking Journal; Mar 1998; 90, 3; Business Premium Collection.
}

(c) Southern Regional Science Association 2020. 
increases economies of scale. Larger banks can spread loan risks across more assets and are less prone to state and regional economic shocks than small, locally owned and regional banks (Morgan et al., 2004; Dick, 2007). Larger banks have more assets and their economies of scale allow them to offer premium services, such as revolving lines of credit, on-line lending, and business credit cards that small banks struggle to provide. Larger banks can also provide loans to small businesses at better rates because there is less risk (Berger and Udell, 1996; Erel, 2011). Rice and Strahan (2010) find that the proliferation of branch banking has reduced loan rates to small businesses and increased the likelihood that small businesses will use a loan. They find no effect of branch banking and amount of loan secured. From this perspective, a lower concentration of locally owned banks in non-metropolitan economies may mean more credit is available, which will increase establishment births and establishment deaths.

Market Concentration Hypotheses: In the regional economy, the concentration of independent local banks is:

1. Negatively related to business births.

2. Negatively related to business deaths.

\section{RELATIONSHIP LENDING AND LOCAL BANKING}

Much of the research on the impact of the proliferation of interstate banking and financial sector restructuring has focused on national trends and metropolitan economies (Ergungor, 2010; Rice and Strahan, 2010; Erel, 2011). There is a separate concern about these patterns and how they affect rural communities. A competing framework combines elements of population ecology, absentee-ownership, and relational lending. Historically, non-metropolitan America local businesses and community banks formed symbiotic relationships, satisfying the sustenance needs of both lender and borrower. In order for local banks to thrive, they needed local commercial customers (Elyasiani and Goldberg, 2004). The money made from commercial lending prompted reinvestment in local businesses, and by extension, local communities.

Financial sector consolidation altered, somewhat, the symbiosis that existed between local businesses and banks. The bank establishment of a larger bank firm (such as Wells Fargo) is less reliant on the local businesses for sustenance. However, the sustenance needs of the local business did not change. (Avery and Samolyk, 2004) find some support for this argument. They compare the lending patterns of banks consolidated into absentee firms and those consolidated into local community banks and find that small business loan growth flourished in the late 1990s among the latter and stagnated among the former. In an analysis of the 2000-2007 time frame, Mencken and Tolbert (2018) find that the concentration of locallyowned banks in a local economy increased significantly the odds that a business was started and/or expanded during that time frame with a conventional bank loan. Moreover, they find that this effect is significantly stronger in non-metropolitan economies (Mencken and Tolbert, 2018). ${ }^{9}$

\footnotetext{
${ }^{9}$ Mencken and Tolbert (2018) used commuter zones as their unit of analysis, or clusters of counties based on
} 
Small businesses, and particularly those in non-metropolitan economies, have tended to rely upon small, locally owned depository institutions (vs. larger, non-local institutions) and their practices of relational (aka. judgment or 'soft' data) lending for financing (Berger and Udell, 1996; Devaney and Weber, 1995; Berger and Udell, 2002; Collender and Frizell, 2002; Berger and Black, 2007; Boot, 2011). Elyasiani and Goldberg (2004) report that the average length of relationship between a small business and financial institution is 7.7 years. Oftentimes, the loan officer has extensive personal and professional relationships in the community and uses her/his networks to gather additional information about the business from customers and suppliers. This 'embeddedness' also allows the loan officer to consider the personal qualities of the person seeking the loan, such as trustworthiness.

Others have argued that local banks in rural communities use these information networks to know their customers better. According to DeYoung et al. (2012), the rate of default for locally owned rural banks is much lower than the national rate. There are two reasons provided for this finding. First, the networks of information in rural communities allows bankers to know their customers better than data from a portfolio. This allows bankers to reduce loan risk. Second, the social capital of small communities may reduce the risk of default. In the context of their study, to default on a loan is to default on a friend/neighbor (instead of impersonal corporation in an urban setting). This could be very damaging to the community reputation of the business owners, thus making paying off the loan a top priority. Kandilov and Kandilov (2017) find similar results for farm loans. DeYoung et al. (2012) conclude that the relational nature of local rural lending offsets the 'scale' advantages of large absentee firms touted by proponents of the market concentration perspective.

Banks lend money where the potential returns are the greatest. While there are some policy and legal lending requirements intended to minimize this effect (e.g., Small Business Association guarantee lending; Community Reinvestment Act of 1977; Gramm-Leach-Bliley Act of 1999 provision allowing small bank access to Federal Home Loan Banks), places with higher risks and less promising returns may not attract capital from larger, non-local banks as easily (Kilkenny, 2002; Shaffer and Collender, 2008). Without the symbiotic relationship between banks and local businesses, many small local businesses may struggle to find conventional financing. These local businesses and their host communities may suffer because of the loss of long-standing relationships with the local bank, or because they cannot use their community reputations to secure credit for a start-up business. In either event, this could lead to slower growth of new businesses, less sustainability, and more business deaths.

While there is some evidence that locally oriented banks are positively associated with business startups, there is little known about local financial institutions' impact on business dissolution. In a contemporaneous view, it follows that where supportive financial institutions engender more startups, there would be fewer firm failures. But, a longitudinal view of rural communities suggests that business deaths could become positively associated with local banks when startups prosper. In previous research (Tolbert et al., 2014) observed a pattern of serial entrepreneurship in their interviews with rural small business owners. These individuals had several small businesses operating at any given time and were constantly searching for new opportunities. They reported starting new businesses and closing existing ones frequently. One respondent noted that she would give her new enterprises about six

commute-to-work patterns from the 2000 Census.

(C)Southern Regional Science Association 2020. 
months to pan out before moving on to other enterprises. This rural American version of creative firm destruction could clearly occur in areas where independent local banks effectively promote business churning by supporting entrepreneurs with good track records. A longitudinal approach that spans the recent restructuring of rural banking could therefore show a positive association between the presence of local banks and business deaths.

The literature review of financial restructuring, the importance of local banks for rural U.S. small businesses, and serial entrepreneurship activity leads to the following hypotheses:

Serial Entrepreneurship Hypotheses: In the regional economy, the concentration of independent local banks is:

1. Positively related to business births.

2. Positively related to business deaths.

\section{METHODS AND DATA}

\subsection{Methods}

This analysis uses two measures of local business dynamics and growth as dependent variables: (1) establishment births and (2) establishment deaths. Specifically, we use the share of employer establishments in a county that are births or deaths. ${ }^{10}$ To examine these hypotheses, we propose a series of panel and spatial panel regression models using annual county-level data from 1980 to 2010 as the unit of analysis. We regress establishment births and deaths (in separate regressions) on the interaction between the percent of county banks that are independent local and indicator variables for metropolitan, micropolitan, and rural non-core counties.

The regressions begin with the standard regional economics approach of lagging values all independent variables, to examine the relationship between local ownership of banks and establishment births and deaths. Thus for columns (1) and (2) of Tables 2-4, the main identifying assumption is the lack of temporal dynamics in potentially omitted variables, which is implicit in the use of lags (Bellemare et al., 2017). Implicit in this approach, however, is that if unobservables at time $t-10$ are causally associated with unobservables at time $t$, and in presence of selection on unobservables, columns (1) and (2) may represent biased estimates. However, this bias would only exist in terms of within-county confounding unobservables because of the use of individual fixed effects in the estimations, which eliminates potential time-invariant heterogeneity. Nevertheless, we interpret the results throughout as suggestive evidence and do not argue a causal marginal effect interpretation in the results.

To check robustness of these results, we also estimate a difference equation, such that we regress $y_{t+10}-y_{t}$ on $x_{t}$ and display those results in columns (3) and (4). This approach

\footnotetext{
${ }^{10}$ This approach measures the dependent variables as shares, to look specifically at compositional effects, but in turn does not allow the market structure to have an aggregate effect. Following Cetorelli and Strahan (2006) and Francis et al. (2008), we tested robustness to alternative measures related to the number or the growth of establishments created/destroyed per capita. The results are robust to these alternative measures such as "births per 1000 people" or "births per 1000 establishments."
}

(c)Southern Regional Science Association 2020. 
assumes that future growth rates of the dependent variables do not affect current levels of explanatory variables and is common in the literature (Levine et al., 2002; Lobao et al., 2016), though again, we interpret the results throughout as suggestive evidence and do not argue a causal marginal effect interpretation in the results. To further support this endeavor, we use long lags of 10 years and test both the effect of future levels and the future growth over those 10 years. The model measures all independent variables at the beginning year, which includes the years between 1980 and 2000, and all dependent variables are the future levels or growth over the respective future 10 years between 1990 and 2010. This approach allows us to compare one set of regressions that uses annual data (1980-2010), which are displayed in Tables 2-4, with another set of regressions that uses decennial data (1980, 1990, 2000, and 2010), which are displayed in Appendix Tables A1-A2. The results are generally robust to alternative shorter time lags, such as 5-year lags. We use the decennial data regressions to test the robustness of the results to the inclusion of additional control variables often found in regional growth literature to account for local and neighboring conditions, which are only available in decennial years. We include standardized county population in all regressions, as it is one of the few control variables available annually over the time period under consideration.

A difficulty with using county-level data is that the units result from arbitrarily drawn political boundaries, rather than logically drawn economic boundaries. When modeling effects on small geographic regions, spatial spillover effects are likely (Rey and Montouri, 1999; Rupasingha et al., 2002; Rey and Janikas, 2005). Such effects are common in regional growth literature and would at best leave the OLS regression inefficient and at worst bias the results (LeSage and Fischer, 2008). In the context of this article, there are concerns of spatial spillover effects in both independent and dependent variables. For example, a bank may influence the birth or death of an establishment in an adjacent county if that establishment uses the bank as a closer alternative to banks in its own county. If this is the case, the standard county-level panel model results may understate or overstate the effect of local ownership of banks by omitting the spillover effect. Spillovers in the dependent variable may also be a concern, as adjacent births/deaths may influence local births/deaths directly through industrial cluster effects or as a proxy for regional economic trends. ${ }^{11}$

Following the suggestions of LeSage and Pace (2009); Elhorst (2010), we first estimate the more general Fixed Effects Spatial Durbin Model (FE SDM), given in Equation (1), where $W$ is a contiguity spatial weighting matrix. ${ }^{12}$ Then, we test the restrictions imposed Fixed

\footnotetext{
${ }^{11}$ While one could conceivably control for some spatial relationships with a fixed effects model, there are logical spillover effects from a locally owned bank (i.e. an establishment may simply use a locally owned bank in an adjacent county); and it may be important to account for and quantify the extent to which these spatial effects influence estimates of the effects of local ownership of banks. Note also that the OLS estimator applied to spatially dependent data in a global model will not provide the proper marginal effects as $\beta=\left(I_{n}-\rho W\right)^{-1} \beta$

${ }^{12}$ LeSage (2014) label the argument that "estimates and inferences from spatial regression models are sensitive to particular specifications used for the spatial weight structure" as "The Biggest Myth in Spatial Econometrics." We additionally find that the estimates are robust to banded inverse-distance specifications of the weighting matrix, so we use a contiguity matrix for sake of easing interpretation. Further, following Elhorst (2014), it is common practice to normalize $W$ such that the elements of each row sum to unity for ease of interpretation. Since $W$ is nonnegative, normalization ensures that all weights are between 0 and 1.
}

(c)Southern Regional Science Association 2020. 
Effects Spatial Auto-Regressive model (FE SAR) and Fixed Effects Spatial Error Model (FE SEM). Specifically, if $\theta=0$ and $\rho \neq 0$, the model collapses to SAR, while if $\theta=-\beta_{\rho}$, then the model is a SEM. Statistical significance of the spatial lag of the dependent variable $(\rho)$ and $x^{2}$ test results are given under each regression column and do confirm the statistical significance of spatial spillover effects in both the dependent and independent variables (indicating that the SDM is generally preferred to the SAR and SEM models) in most cases. ${ }^{13} \mathrm{We}$ do not test the SAC panel model as LeSage and Pace (2009) show that a linear combination of the SAR and SEM models is actually the SDM model (LeSage, 2014). ${ }^{14}$ Therefore, we estimate:

$$
y_{i, t+10}=\rho W y_{i t}+\beta X_{i t}+\theta W X_{i t}+\alpha_{i}+\gamma_{t}+u_{i t}
$$

There are additional benefits of using the FE SDM, such as controlling for the influence of omitted variables and thereby mitigating the need to instrument for endogenous variables (Brasington and Hite, 2005). Although we do find statistically significant spatial dependence in the dependent variables (which is shown below in the significance of $\rho$ ), some researchers argue that an alternative model to avoid (potential) concerns of endogeneity in some spatial models is the Spatial Lag of X (SLX) model (Gibbons and Overman, 2012; Vega and Elhorst, 2015). The results are generally robust to the use of the SLX model. We focus on the FE SDM results here, though the results of the many spatial models are qualitatively similar.

Finally, the specification of the control variables is subject to some debate. This debate continues to some extent because, for example, theory explains that human capital and local fiscal policies matter, but are less informative regarding which specific variables to include (Deller and Lledo, 2007). Studies use various techniques to investigate the correct historical information including extreme bounds testing (Levine et al., 2002) and Bayesian Model Averaging techniques (Barro and Sala-i Martin, 2004; LeSage and Parent, 2007). We draw on the findings of this (and other) past work to motivate the set of variables included in Decennial Census data robustness check, but concerns may remain of variable specification because the omitted variables problem likely arises when handling regional data samples. This concern provides the final motivation for the SDM: LeSage and Pace (2009) demonstrate that parameter estimates of the SDM are not affected by the magnitude of the spatial dependence in the omitted variables and conclude that this feature of the SDM is a strong motivation for its use when using regional data.

\subsection{Data}

The key independent variable of interest in the regressions is the share of traditional banking establishments in a county that are locally owned. The results are robust to alternative measures such as local bank counts and local banks per 1000 people, per 1000 establishments, or

\footnotetext{
${ }^{13}$ The exceptions are a few cases in which the spatial lags of the explanatory variables are found to be insignificant. In this case, though an SDM is still a consistent estimator, the spatially weighted explanatory variables provide no insight and a SAR model would suffice. We leave all the displayed spatial results as SDM to avoid confusion on the types of models being run and note that the SAR model results are nearly identical in these cases.

${ }^{14}$ When examining growth in the dependent variables, Equations (1) and (2) would contain $y_{i, \Delta t}$, rather than $y_{i, t+10}$.
}

(C)Southern Regional Science Association 2020. 
Table 1: Summary Statistics

\begin{tabular}{lcccc}
\hline \hline & $(1)$ & $(2)$ & $(3)$ & $(4)$ \\
Variables & Standard & Available & \\
\hline Percent banks local owned & 34.200 & 29.590 & Annual & LBD \\
Establishment births & $10.210 \%$ & 4.171 & Annual & LBD \\
Establishment deaths & $8.942 \%$ & 2.284 & Annual & LBD \\
Metropolitan $(1=$ yes $)$ & 0.345 & 0.475 & Annual & U.S. Census \\
Micropolitan $(1=$ yes $)$ & 0.222 & 0.416 & Annual & U.S. Census \\
Non-core $(1=$ yes $)$ & 0.433 & 0.496 & Annual & U.S. Census \\
Population & $85,854.450$ & $281,285.700$ & Annual & BEA \\
Bachelor's degree percent & 9.787 & 5.250 & Decennial & U.S. Census \\
Poverty population percent & 15.252 & 6.939 & Decennial & U.S. Census \\
Black population percent & 8.780 & 14.487 & Decennial & U.S. Census \\
Asian population percent & 2.591 & 4.762 & Decennial & U.S. Census \\
Hispanic population percent & 5.697 & 11.827 & Decennial & U.S. Census \\
\hline \hline
\end{tabular}

Notes: Abbreviations are Longitudinal Business Database (LBD), Bureau of Economic Analysis (BEA)

location quotient measures. This robustness check is important because it may be important to separate the effects of the market share of local banks (share of banks that are local) and the effects from the overall bank concentration (banks per capita). The dependent variables that we use to measure business dynamics include the share of county employer establishments that are births (new establishments) and deaths (the final year of an establishment). We create these measures from limited access and near-comprehensive Longitudinal Business Database (LBD), accessed in a Federal Statistical Research Data Center (FSRDC), which refines "deaths" retrospectively to only include true "deaths" (establishments that do not return to existence in the future) and "births" to only include new employer identification numbers (establishments filing as a new entity in the U.S. taxation system, rather than establishments that cease operations temporarily). We merge in numerous publicly available control variables common to regional analysis, also detailed in Table 1 . Note that, though we include a 3-category multinomial to cover rurality, our spatial panel models control for the metropolitan status of the adjacent county as well, in effect giving us a more detailed control similar to the 9-category U.S. Department of Agriculture Rural-Urban Continuum Codes.

Table 1 also includes variables drawn from the Decennial Census. We use these additional control variables in a regression that only uses the decennial years. This regression serves as a robustness check because it is also able to include control variables that are only available from the Decennial Census. The additional variables are common in regional growth and migration literature: percent of people who have a bachelor's degree or higher as a proxy for human capital; rurality (Deller et al., 2001; Wu and Gopinath, 2008; Rupasingha et al., 2015) and percent of individuals that are Black, Asian, and Hispanic as a proxy for relative structural inequalities related to race or ethnicity, and location (Voss et al., 2006; Lobao et al., 2016); and unemployment and poverty rates as proxies for the aggregate strength 
of the local labor market (Partridge and Rickman, 2006; Lobao et al., 2016). Table 2 uses every year of data from 1980 to 2010, but we also include the results found when using only decennial data and more extensive controls in tables A1-A2. ${ }^{15}$ The effects found using only decennial years and more extensive controls are larger, but remain generally the same in terms of sign and statistical significance. Thus, we focus on the results using annual data, rather than decennial data to err on the side of conservatism. ${ }^{16}$

\section{RESULTS}

\subsection{Panel Regressions}

This section begins with some classic panel regression techniques including pooled OLS (POLS) and Fixed Effects (FE) regressions. While we are interested in the between variation that is measured in the POLS regressions, as noted in the methods section, measures of business dynamics, such as establishment births and deaths, may depend on important and hard-to-observe characteristics of the local economy and geography that correlate with socioeconomic measures. With the Hausman test indicating significance of time-invariant fixed effects, we include FE regressions to test the robustness of the estimates to county-specific unobserved characteristics. The POLS regressions control for these unobserved effects to the extent to which they are determined by metropolitan, micropolitan, and noncore status. The dependent variables in columns (1) and (2) of Table 2 is the 10-year future establishment births, while the dependent variable in columns (3) and (4) is the 10-year growth in establishment births. Table 2 uses every year of data from 1980 to 2010. We also conducted analysis using only decennial data and more extensive controls.

Table 2 is the first examination of the stark effect of the decline of local ownership of traditional banking institutions in micropolitan and rural non-core versus metropolitan areas. The results in columns (3) and (4) indicate that a 1 percentage point increase in the share of metropolitan county banks that are locally owned decreases the growth in establishment births by between 0.0029 and 0.0095 percentage points, on average. The interaction between metropolitan status and local ownership, however, indicates a larger and opposite effect in rural non-core areas. Specifically, a 1 percentage point increase in the share of rural noncore county banks that are locally owned increases the change in establishment births in that county by between 0.0043 and 0.0082 percentage points, on average. Columns (1) and (2) tell a similar story with a 1 percentage point increase in the share of metropolitan county banks that are locally owned decreasing the future establishment births by between 0.0040 and 0.0122 percentage points, on average. However, a 1 percentage point increase in the share of rural non-core county banks that are locally owned increases the establishment births in that county by between 0.0092 and 0.0125 percentage points, on average. In 2010, the

\footnotetext{
${ }^{15}$ Note that the observations, despite simply being the number of included continental U.S. counties are rounded in all the regression results tables. This is a required suppression by the U.S. Census Bureau disclosure avoidance regulations.

${ }^{16}$ We also note that based on estimates omitted (for readability) that the results are similar to those in the appendix when using only the decennial years, but without the additional control variables. Thus, the change in coefficient magnitude appears to result mostly from the reduction in observations, rather than the inclusion of additional control variables.
}

(c)Southern Regional Science Association 2020. 
Table 2: Panel Regressions Using Annual Establishment 1980-2010 Births

\begin{tabular}{lcccc}
\hline \hline & $(1)$ & $(2)$ & $(3)$ & $(4)$ \\
& Future Births & Future Births & Births & Births \\
& POLS & FE & Growth POLS & Growth FE \\
\hline Local owned & $-0.004^{* *}$ & $-0.012^{* * *}$ & $-0.003^{* *}$ & $-0.010^{* * *}$ \\
Local owned and micro & $(0.002)$ & $(0.0020)$ & $(0.0012)$ & $(-.0028)$ \\
& 0.001 & $0.006^{* * *}$ & -0.000 & 0.0003 \\
Local owned and non-core & $(0.002)$ & $(0.002)$ & $(0.002)$ & $(-.003)$ \\
& $0.013^{* * *}$ & $0.025^{* * *}$ & $0.007^{* * *}$ & $0.018^{* * *}$ \\
Standardized population & $(0.002)$ & $(0.002)$ & $(0.001)$ & $(-0.003)$ \\
& $0.057^{* *}$ & $1.185^{* *}$ & $0.056^{* * *}$ & $1.438^{* *}$ \\
Micropolitan & $(0.023)$ & $(0.470)$ & $(0.012)$ & $(0.590)$ \\
& $-0.877^{* * *}$ & & -0.013 & \\
Non-core & $(0.114)$ & & $(0.061)$ & \\
Constant & $-1.450^{* * *}$ & & $-0.367^{* * *}$ & \\
& $(0.112)$ & & $(-0.062)$ & \\
\hline Observations & $20.530^{* * *}$ & $19.830^{* * *}$ & $10.820^{* * *}$ & $10.780^{* * *}$ \\
R-squared & $(0.226)$ & $(0.215)$ & $(0.220)$ & $(0.240)$ \\
Year FE & 64,000 & 64,000 & 64,000 & 64,000 \\
State FE & 0.465 & 0.480 & 0.410 & 0.414 \\
\hline \hline
\end{tabular}

Notes: Robust standard errors in parentheses

${ }^{* * *} p<0.01,{ }^{* *} p<0.05,{ }^{*} p<0.1$

average number of establishments in metropolitan, micropolitan, and rural non-core county types were 5873, 1041, and 336, respectively. Thus, a 10 percentage point increase in the share of rural non-core county banks that are locally owned is associated with an increase in the employer establishment births in that county by between $30(0.0092 \times 336 \times 10)$ and 40 $(0.0125 \times 336 \times 10)$ on average. In all of these regressions, the effect of local ownership of banks is slightly negative or statistically insignificant in micropolitan counties. With the omitted reference category being metropolitan status, the indicator variables for micropolitan and non-core status are generally statically significant and negative.

Table 3 contains the same regressions, but uses the share of county establishments that are deaths as the dependent variable. These tables again highlight an opposite effect of the local ownership of banks between metropolitan and non-core counties. Specifically, Table 3 shows a negative effect of local ownership in metropolitan counties on deaths, and a positive effect in non-core counties. To summarize our panel regression results, in rural non-core counties, local ownership of banks generally increases local establishment births and deaths, while having the opposite effects in metropolitan counties.

(c)Southern Regional Science Association 2020. 
Table 3: Panel Regressions Using Annual Establishment 1980-2010 Deaths

\begin{tabular}{|c|c|c|c|c|}
\hline & $\begin{array}{c}(1) \\
\text { Future Deaths } \\
\text { POLS }\end{array}$ & $\begin{array}{c}(2) \\
\text { Future Deaths } \\
\text { FE }\end{array}$ & $\begin{array}{c}(3) \\
\text { Deaths } \\
\text { Growth POLS }\end{array}$ & $\begin{array}{c}(4) \\
\text { Deaths } \\
\text { Growth FE }\end{array}$ \\
\hline Local ownership & $\begin{array}{c}0.002 \\
(0.001)\end{array}$ & $\begin{array}{l}-0.001 \\
(0.001)\end{array}$ & $\begin{array}{c}-0.003^{* * *} \\
(0.001)\end{array}$ & $\begin{array}{c}-0.003^{*} \\
(0.002)\end{array}$ \\
\hline Local owned and micro & $\begin{array}{l}0.003^{*} \\
(0.002)\end{array}$ & $\begin{array}{c}0.005^{* * *} \\
(0.001)\end{array}$ & $\begin{array}{c}0.001 \\
(0.001)\end{array}$ & $\begin{array}{c}0.002 \\
(0.002)\end{array}$ \\
\hline Local owned and non-core & $\begin{array}{l}0.002^{*} \\
(0.001)\end{array}$ & $\begin{array}{c}0.004^{* * *} \\
(0.001)\end{array}$ & $\begin{array}{c}0.002 \\
(0.001)\end{array}$ & $\begin{array}{c}0.002 \\
(0.002)\end{array}$ \\
\hline Standardized population & $\begin{array}{c}0.112^{* * *} \\
(0.037)\end{array}$ & $\begin{array}{c}0.068 \\
(0.061)\end{array}$ & $\begin{array}{c}0.030^{* * *} \\
(0.009)\end{array}$ & $\begin{array}{c}-0.343^{* * *} \\
(0.114)\end{array}$ \\
\hline Micropolitan & $\begin{array}{c}-0.407 * * * \\
(0.076)\end{array}$ & & $\begin{array}{c}-0.209 * * * \\
(0.041)\end{array}$ & \\
\hline Non-core & $\begin{array}{c}-0.361^{* * *} \\
(0.086)\end{array}$ & & $\begin{array}{c}-0.211^{* * *} \\
(0.044)\end{array}$ & \\
\hline Constant & $\begin{array}{c}7.475^{* * *} \\
(0.081)\end{array}$ & $\begin{array}{c}7.349^{* * *} \\
(0.048)\end{array}$ & $\begin{array}{c}-3.178^{* * *} \\
(0.066)\end{array}$ & $\begin{array}{c}-3.343^{* * *} \\
(0.083)\end{array}$ \\
\hline Observations & 64,000 & 64,000 & 64,000 & 64,000 \\
\hline R-squared & 0.262 & 0.195 & 0.172 & 0.166 \\
\hline Year FE & YES & YES & YES & YES \\
\hline State FE & YES & & YES & \\
\hline
\end{tabular}

Notes: Robust standard errors in parentheses

${ }^{* * *} p<0.01,{ }^{* *} p<0.05,{ }^{*} p<0.1$

\subsection{Spatial Panel Regressions}

As we noted in the methods section, there are concerns of spatial spillover effects in both independent and dependent variables. Put simply, a bank may influence the birth or death of an establishment in an adjacent county because that establishment simply uses a closer bank in an adjacent county. If this is the case, standard panel model results may understate the effect of local ownership of banks by omitting this spillover effect. Tables 4 and 5 present the average direct effect, average indirect (spillover) effect, and average total effect, all of which have the conventional (marginal effect) interpretation in their respective directions (LeSage and Pace, 2009).

The FE SDM direct effect estimates of the impact of locally owned banks are not directly comparable to the standard panel model results because the SDM direct effects also include feedback effects. Nonetheless, the results are qualitatively similar to the FE panel models previously discussed. Tables 4 and 5 both also show statistically significant indirect (spillover) effects that double the estimated effects of the local ownership of banks. In a metropolitan county, for example, the estimated direct effect of a 1 percentage point increase in the local ownership of banks is a reduction by 0.0121 percentage points in the share of future establishment births, while the indirect effect is an additional reduction by 0.0136 percentage points. Thus, the total estimated marginal effect becomes -0.0256 . Non-core 
Table 4: FE SDM Marginal Effects Using Annual Data $1980-2010$

\begin{tabular}{|c|c|c|}
\hline & $\begin{array}{c}\text { (1) } \\
\text { Future Births }\end{array}$ & $\begin{array}{c}\text { (2) } \\
\text { Births Growth }\end{array}$ \\
\hline \multicolumn{3}{|l|}{ Direct Effects } \\
\hline Local ownership & $\begin{array}{c}-0.012^{* * *} \\
(0.002)\end{array}$ & $\begin{array}{c}-0.009^{* * *} \\
(0.003)\end{array}$ \\
\hline Local owned and micro & $\begin{array}{c}0.006^{* * *} \\
(0.002)\end{array}$ & $\begin{array}{l}-0.000 \\
(0.003)\end{array}$ \\
\hline Local owned and non-core & $\begin{array}{c}0.024^{* * *} \\
(0.002)\end{array}$ & $\begin{array}{c}0.017^{* * *} \\
(0.003)\end{array}$ \\
\hline Standardized population & $\begin{array}{c}1.198^{* * *} \\
(0.493)\end{array}$ & $\begin{array}{l}1.444^{* *} \\
(0.606)\end{array}$ \\
\hline \multicolumn{3}{|l|}{ Indirect Effects } \\
\hline Local ownership & $\begin{array}{c}-0.014^{* * *} \\
(0.005)\end{array}$ & $\begin{array}{c}-0.014^{* *} \\
(0.006)\end{array}$ \\
\hline Local owned and micro & $\begin{array}{c}0.017^{* *} \\
(0.007)\end{array}$ & $\begin{array}{c}0.005 \\
(0.010)\end{array}$ \\
\hline Local owned and non-core & $\begin{array}{c}0.021^{* * *} \\
(0.006)\end{array}$ & $\begin{array}{l}0.014^{* *} \\
(0.007)\end{array}$ \\
\hline Standardized population & $\begin{array}{c}0.582 \\
(0.377)\end{array}$ & $\begin{array}{c}1.308^{* * *} \\
(0.477)\end{array}$ \\
\hline \multicolumn{3}{|l|}{ Total Effects } \\
\hline Local ownership & $\begin{array}{c}-0.026^{* * *} \\
(0.005)\end{array}$ & $\begin{array}{c}-0.023^{* * *} \\
(0.007)\end{array}$ \\
\hline Local owned and micro & $\begin{array}{c}0.023^{* * *} \\
(0.008)\end{array}$ & $\begin{array}{c}0.005 \\
(0.011)\end{array}$ \\
\hline Local owned and non-core & $\begin{array}{c}0.045^{* * *} \\
(0.006)\end{array}$ & $\begin{array}{c}0.032^{* * *} \\
(0.008)\end{array}$ \\
\hline Standardized population & $\begin{array}{c}1.780 * * * \\
(0.665)\end{array}$ & $\begin{array}{c}2.751^{* * *} \\
(0.835)\end{array}$ \\
\hline$\rho$ & $\begin{array}{c}0.229 * * * \\
0.015\end{array}$ & $\begin{array}{c}0.249 * * * \\
0.014\end{array}$ \\
\hline Observations & 64,000 & 64,000 \\
\hline Year FE & YES & YES \\
\hline$H_{0}: W X=0$ & $X^{2}(4)=9.68^{* *}$ & $X^{2}(4)=6.42$ \\
\hline
\end{tabular}

counties exhibit the same pattern in the opposite direction. The estimated direct effect of a 1 percentage point increase in the local ownership of banks for a non-core county is an increase by $0.0122(0.0243-0.0121)$ percentage points in future establishment births, while the indirect effect is an increase by $0.0070(0.0206-0.0136)$ percentage points. Thus, the total estimated effect for local ownership in a non-core county becomes 0.0193 . Note that one can 
Table 5: FE SDM Marginal Effects Using Annual Data $1980-2010$

\begin{tabular}{|c|c|c|}
\hline & $\begin{array}{l}\text { (1) } \\
\text { Future Deaths }\end{array}$ & $\begin{array}{c}(2) \\
\text { Deaths Growth }\end{array}$ \\
\hline \multicolumn{3}{|l|}{ Direct Effects } \\
\hline Local ownership & $\begin{array}{l}-0.001 \\
(0.001)\end{array}$ & $\begin{array}{l}-0.003 \\
(0.002)\end{array}$ \\
\hline Local owned and micro & $\begin{array}{c}0.005^{* * *} \\
(0.001)\end{array}$ & $\begin{array}{c}0.002 \\
(0.002)\end{array}$ \\
\hline Local owned and non-core & $\begin{array}{c}0.004^{* * *} \\
(0.001)\end{array}$ & $\begin{array}{c}0.002 \\
(0.002)\end{array}$ \\
\hline Standardized population & $\begin{array}{c}0.055 \\
(0.059)\end{array}$ & $\begin{array}{c}-0.352^{* * *} \\
(0.139)\end{array}$ \\
\hline \multicolumn{3}{|l|}{ Indirect Effects } \\
\hline Local ownership & $\begin{array}{l}-0.001 \\
(0.002)\end{array}$ & $\begin{array}{l}-0.002 \\
(0.003)\end{array}$ \\
\hline Local owned and micro & $\begin{array}{c}0.004 \\
(0.003)\end{array}$ & $\begin{array}{c}0.003 \\
(0.005)\end{array}$ \\
\hline Local owned and non-core & $\begin{array}{c}0.002 \\
(0.002)\end{array}$ & $\begin{array}{l}-0.000 \\
(0.004)\end{array}$ \\
\hline Standardized population & $\begin{array}{c}0.521^{* * *} \\
(0.148)\end{array}$ & $\begin{array}{l}0.651^{* *} \\
(0.283)\end{array}$ \\
\hline Total Effects & & \\
\hline Local ownership & $\begin{array}{l}-0.003 \\
(0.002)\end{array}$ & $\begin{array}{l}-0.004 \\
(0.004)\end{array}$ \\
\hline Local owned and micro & $\begin{array}{c}0.009^{* * *} \\
(0.003)\end{array}$ & $\begin{array}{c}0.005 \\
(0.005)\end{array}$ \\
\hline Local owned and non-core & $\begin{array}{c}0.006^{* * *} \\
(0.002)\end{array}$ & $\begin{array}{c}0.001 \\
(0.004)\end{array}$ \\
\hline Standardized population & $\begin{array}{c}0.575^{* * *} \\
(0.157)\end{array}$ & $\begin{array}{c}0.299 \\
(0.308)\end{array}$ \\
\hline$\rho$ & $\begin{array}{c}0.063^{* * *} \\
0.006\end{array}$ & $\begin{array}{c}0.074^{* * *} \\
0.006\end{array}$ \\
\hline Observations & 64,000 & 64,000 \\
\hline Year FE & YES & YES \\
\hline$H_{0}: W X=0$ & $X^{2}(4)=15.52^{* *}$ & $X^{2}(4)=6.90$ \\
\hline
\end{tabular}

interpret the indirect effect estimates in either direction. That is, the indirect effect can be interpreted as either the combined effect of all adjacent counties on a particular county, or the combined effect of a particular county on all adjacent counties (LeSage and Pace, 2009). In the context of this article, either interpretation is sensible. Local ownership of local banks in a particular county affects adjacent counties' business dynamics, and local ownership of

(C)Southern Regional Science Association 2020. 
local banks in adjacent counties affects a particular county's business dynamics.

The rest of Table 4 and Table 5 show similar results to our non-spatial FE panel models, with most regressions showing statistically significant indirect effects that increase the total marginal effect. Thus, using these spatial panel regressions allows an important change to the results summary: the results show that local ownership of banks in a rural non-core county increases regional establishment births and deaths. Conversely, local ownership of banks in a metropolitan county decreases regional establishment births and does not have a statistically significant impact on local or regional establishment deaths. ${ }^{17}$

\section{DISCUSSION}

The results from our analysis find support for both hypotheses presented above. The 1994 Riegle-Neal Interstate Banking and Branching Efficiency Act sought to remove the inefficiencies and ease interstate banking restrictions. Critics of the legislation, namely small, local community banks, feared an oligopoly in the national banking market and a decline in available financing for rural business start-ups (DeYoung et al., 2012). Rural communities were concerned that the loss of local banks would affect access to small business lending in rural communities by linking conventional loans more tightly to hard data credit scoring. Traditionally, these communities have relied upon conventional banking loans from local banks at a greater rate than comparable businesses in urban areas (Mencken and Tolbert, 2016, 2018).

Proponents of deregulation pointed to industry safeguards, such as anti-trust laws, state and federal regulator oversight of all mergers, and most importantly, the Community Reinvestment Act which directs banks to make funds available to the entire community they serve (Johnson and Sarkar, 1996; Friedman and Squires, 2005). However, a sizeable volume of research on this topic in the field of finance concedes that consolidation in the financial sector at the national level will lead to a reduction of relationship lending, particularly for small businesses in locales where market concentration is not achieved (Berger and Udell, 2002; Berger et al., 2005; Brevoort and Hannan, 2006; Berger et al., 2011). The lack of local ownership of financial institutions could mean less access to conventional capital for local businesses in rural communities (DeYoung et al., 2012).

The results for our model shows that between 1980 and 2010, a period that covers the significant consolidation of the financial sector at the level of the firm, new business growth was greater in rural non-core counties, compared to metropolitan and micropolitan counties, which had greater concentrations of locally owned banks. Based on previous research (see Avery and Samolyk, 2004; Elyasiani and Goldberg, 2004; DeYoung et al., 2012), we expect that the practice of relationship lending between local banks and local businesses was one of the key reasons for the greater growth rates of business start-ups in rural areas. On the

\footnotetext{
${ }^{17}$ An alternative strategy when considering local economic spillover effects is using commuting zones. All U.S. counties used in the above regressions are classified into a commuting zone county group, which consists of one or more counties that are linked economically and socially by commuting patterns or workers (Tolbert and Sizer, 1996). We tested the robustness of our fixed effects panel regression and spatial panel regression results with commuting zones as the unit of analysis. The results are qualitatively similar to the county-level regressions. These results available upon request.
}

(c)Southern Regional Science Association 2020. 
other hand, perhaps a serial entrepreneurship churning thesis explains the increased business deaths in rural areas. While these findings and conclusions would support the relational lending/local banking hypothesis for business births and the serial entrepreneurship hypothesis for business deaths, it is still conjecture; we do not have data on the nature of relationships between local business growth and local banking. What we have at this point is a reasonable expectation, based on theory and previous research, and a significant statistical correlation over time, which is robust over a variety of different model types.

The data also show support for the market concentration hypothesis. In metropolitan counties, a higher concentration of non-local banks (and presumably branches of larger banks) has a positive effect on new business growth. We maintain that this finding supports the market concentration benefits from the consolidation and restructuring in the financial services sector. In urban areas, the competitive rates and volume of lending lead to a greater supply of available start-up capital. This leads to greater growth. In line with this finding is the expected negative effects of non-local banking on business deaths in metropolitan counties. Non-local banks rely more on hard-data and credit scoring to process loan applications. It is expected that these lead to fewer business deaths because of better information and reduced risk. Our results, however, show that when non-local banking increases in metropolitan areas, both births and deaths - or churn - increases.

Our findings are also at odds with the predictions of the relational lending/local banking hypothesis. DeYoung et al. (2012) speculate that bank failure rates are lower in rural communities because banks in these geographies are more likely to use the information embedded in the relationship networks throughout the community in the process of making the loan decision. Based on this logic, we expected to find that there would be slower death rates in counties with a higher proportion of local banks. We find the opposite. One interpretation of this is to conclude that the market concentration perspective applies well to business sustainability and survival in all county types, while the relationship lending/local bank hypothesis applies well to business start-ups in rural economies. The applicability of each theory is contingent upon both geography and location in the business life cycle.

One alternative explanation is that the results for business death growth might mask the size of the businesses in question, and the motivation of the owners. Serial entrepreneurship may be generating business churning in rural areas, as Tolbert et al. (2014) suggest. Perhaps the positive effects of local bank concentration in rural non-core counties on both business start-ups and deaths reflects this type of 'churning' that is unique to small communities in which the relatively successful (and credit worthy) entrepreneurs are trying to maximize all possible opportunities in niches with fewer opportunities. It is a theory is worth further pursuit.

The implications of this research are important for both rural sociology, regional economics, and finance. Community well-being in rural sociology is a function of the many forms of capital available to communities (Flora et al., 2015). Much of this past research has focused exclusively on political and social capital ((Tolbert et al., 1998, 2002; Coffé, 2009; Besser and Miller, 2013b,a). Our results show that local finance should have a positive effect on new business growth in rural communities well-being by improving business dynamics. It allows local business owners in rural America greater access to the types of capital that often prove most useful and affordable to start and maintain businesses (Black and Strahan, 2002;

(C)Southern Regional Science Association 2020. 
Fairlie and Robb, 2007; Robb and Fairlie, 2007; Collender and Shaffer, 2009). We contend that local independent banks are key venues in which social capital can be denominated as business capital. The loss of those banks moves many rural communities closer to social disintegration.

Moreover, the research on entrepreneurship dynamism and rural economic development shows that a thriving small business sector leads to stronger communities. An independent middle class of local business owners creates the type of climate in which community members can utilize their political and social capital to address social problems. Empirical research on this topic indicates that such communities have better public health, less net out-migration, less unemployment, and fewer crime related problems (Irwin et al., 1999; Lee, 2008; Blanchard et al., 2011). Our analysis shows that access to local capital is important for local business birth in rural locales.

\section{REFERENCES}

Avery, Robert B. and Katherine A. Samolyk. (2004) "Bank Consolidation and Small Business Lending: The Role of Community Banks," Journal of Financial Services Research, 25(2-3), 291-325.

Barro, Robert and Xavier Sala-i Martin. (2004) Economic Growth. MIT Press, Cambridge, MA.

Bellemare, Marc F., Takaaki Masaki, and Thomas B. Pepinsky. (2017) "Lagged Explanatory Variables and the Estimation of Causal Effect," The Journal of Politics, 79(3), 949-963.

Berger, Allen N. and Lamont K. Black. (2007) "Lending Technologies, Bank Size, and Small Business Finance: Extensions and Tests of the Current Paradigm," Federal Reserve Board of Governors Working Paper.

Berger, Allen N. and Lamont K. Black. (2011) "Bank Size, Lending Technologies, and Small Business Finance," Journal of Banking \& Finance, 35(3), 724-735.

Berger, Allen N., Adrian M. Cowan, and W. Scott Frame. (2011) "The Surprising Use of Credit Scoring in Small Business Lending by Community Banks and the Attendant Effects on Credit Availability, Risk, and Profitability," Journal of Financial Services Research, $39(1-2), 1-17$.

Berger, Allen N., Nathan H. Miller, Mitchell A. Petersen, Raghuram G. Rajan, and Jeremy C. Stein. (2005) "Does Function Follow Organizational Form? Evidence from the Lending Practices of Large and Small Banks," Journal of Financial Economics, 76(2), 237-269.

Berger, Allen N. and Gregory F. Udell. (1995) "Relationship Lending and Lines of Credit in Small Firm Finance," Journal of Business, pp. 351-381.

Berger, Allen N. and Gregory F. Udell. (1996) "Universal Banking and the Future of Small Business Lending," In Saunders, A. and I. Walter, eds., Financial System Design: The Case for Universal Banking. Irwin Publishing: Burr Ridge, IL, pp. 559-627.

Berger, Allen N and Gregory F Udell. (2002) "Small business credit availability and relationship lending: The importance of bank organisational structure," The economic journal, 112(477), F32-F53.

Besser, Terry L. and Nancy J. Miller. (2013a) "Community Matters: Successful Entrepreneur-

(C)Southern Regional Science Association 2020. 
ship in Remote Rural US Locations," The International Journal of Entrepreneurship and Innovation, 14(1), 15-27.

Besser, Terry L. and Nancy J. Miller. (2013b) "Social Capital, Local Businesses, and Amenities in US Rural Prairie Communities," Journal of Rural Studies, 32, 186-195.

Bird, Sharon R. and Stephen G. Sapp. (2004) "Understanding the Gender Gap in Small Business Success: Urban and Rural Comparisons," Gender \& Society, 18(1), 5-28.

Black, Sandra E. and Philip E. Strahan. (2002) "Entrepreneurship and Bank Credit Availability," The Journal of Finance, 57(6), 2807-2833.

Blanchard, Troy C., Charles M. Tolbert, and F. Carson Mencken. (2011) "The Health and Wealth of US Counties: How the Small Business Environment Impacts Alternative Measures of Development," Cambridge Journal of Regions, Economy and Society, 5(1), 149162.

Boot, Arnoud W. A. (2011) "Banking at the Crossroads: How to Deal With Marketability and Complexity?," Review of Development Finance, 1(3-4), 167-183.

Boustanifar, Hamid. (2014) "Finance and Employment: Evidence From US Banking Reforms," Journal of Banking \& Finance, 46, 343-354.

Brasington, David M. and Diane Hite. (2005) "Demand for Environmental Quality: a Spatial Hedonic Analysis," Regional Science and Urban Economics, 35(1), 57-82.

Brevoort, Kenneth P. and Timothy H. Hannan. (2006) "Commercial Lending and Distance: Evidence From Community Reinvestment Act Data," Journal of Money, Credit and Banking, pp. 1991-2012.

Briggeman, Brian C., Charles A. Towe, and Mitchell J. Morehart. (2009) "Credit Constraints: Their Existence, Determinants, and Implications for US Farm and Nonfarm Sole Proprietorships," American Journal of Agricultural Economics, 91(1), 275-289.

Calomiris, Charles W., R. Glenn Hubbard, and James H. Stock. (1986) "Growing in Debt: The 'Farm Crisis' and Public Policy (Working Paper No. 2085)," National Bureau of Economic Research, 1050 Massachusetts Blvd., Cambridge, MA: .

Cetorelli, Nicola and Philip E. Strahan. (2006) "Finance as a Barrier to Entry: Bank Competition and Industry Structure in Local US Markets," The Journal of Finance, 61(1), 437-461.

Coffé, Hilde. (2009) "Social Capital and Community Heterogeneity," Social Indicators Research, 91(2), 155-170.

Collender, Robert N. and Julie A. Frizell. (2002) "Small Commercial Banks and the Federal Home Loan Bank System," International Regional Science Review, 25(3), 279-303.

Collender, Robert N. and Sherrill Shaffer. (2003) "Local Bank Office Ownership, Deposit Control, Market Structure, and Economic Growth," Journal of Banking 6 Finance, 27(1), 27-57.

Collender, Robert N. and Sherrill Shaffer. (2009) "Banking Structure and Employment Growth," Applied Economics, 41(19), 2403-2417.

Craig, Ben R., William E. Jackson III, and James B. Thomson. (2007) "Small Firm Finance, Credit Rationing, and the Impact of SBA-guaranteed Lending on Local Economic Growth," Journal of Small Business Management, 45(1), 116-132.

Deller, Steven and Victor Lledo. (2007) "Amenities and Rural Appalachia Economic Growth," Agricultural and Resource Economics Review, 36(1), 107-132.

Deller, Steven C., Tsung-Hsiu Tsai, David W. Marcouiller, and Donald B. K. English. (2001)

(C)Southern Regional Science Association 2020. 
"The Role of Amenities and Quality of Life in Rural Economic Growth," American Journal of Agricultural Economics, 83(2), 352-365.

Devaney, Mike and Bill Weber. (1995) "Local Characteristics, Contestability, and the Dynamic Structure of Rural Banking: A Market Study," The Quarterly Review of Economics and Finance, 35(3), 271-287.

DeYoung, Robert, Dennis Glennon, Peter Nigro, and Kenneth Spong. (2012) "Small Business Lending and Social Capital: Are Rural Relationships Different," University of Minnesota Workshop on Small Business Lending.

DeYoung, Robert, William C. Hunter, and Gregory F. Udell. (2004) "Whither the Community Bank?," Journal of Financial Services Research, 25(2), 81-84.

Dick, Astrid A.. (2007) "Market Size, Service Quality, and Competition in Banking," Journal of Money, Credit and Banking, 39(1), 49-81.

Dudley, Kathryn Marie. (1996) "The Problem of Community in Rural America," Culture \& Agriculture, 18(2), 47-57.

Elhorst, J. Paul. (2010) "Applied Spatial Econometrics: Raising the Bar," Spatial Economic Analysis, 5(1), 9-28.

Elhorst, J. Paul. (2014) "Linear Spatial Dependence Models for Cross-section Data," In Spatial Econometrics. Springer: pp. 5-36.

Elyasiani, Elyas and Lawrence G. Goldberg. (2004) "Relationship Lending: A Survey of the Literature," Journal of Economics and Business, 56(4), 315-330.

Erel, Isil. (2011) "The Effect of Bank Mergers on Loan Prices: Evidence from the United States," The Review of Financial Studies, 24(4), 1068-1101.

Ergungor, Ozgur Emre. (2010) "Bank Branch Presence and Access to Credit in Low-toModerate Income Neighborhoods," Journal of Money, Credit and Banking, 42(7), 13211349.

Fairlie, Robert W. and Alicia M. Robb. (2007) "Why are Black-owned Businesses Less Successful than White-owned Businesses? The Role of Families, Inheritances, and Business Human Capital," Journal of Labor Economics, 25(2), 289-323.

Flora, Cornelia Butler, Jan. L Flora, and Stephen P. Gasteyer. (2015) Rural Communities: Legacy and Change. Westview Press, Boulder, CO.

Francis, Bill, Iftekhar Hasan, and Haizhi Wang. (2008) "Bank Consolidation and New Business Formation," Journal of Banking \&6 Finance, 32(8), 1598-1612.

Friedman, Samantha and Gregory D. Squires. (2005) "Does the Community Reinvestment Act Help Minorities Access Traditionally Inaccessible Neighborhoods?," Social Problems, $52(2), 209-231$.

Gibbons, Stephen and Henry G. Overman. (2012) "Mostly Pointless Spatial Econometrics?," Journal of Regional Science, 52(2), 172-191.

Gilbert, R. Alton and David C. Wheelock. (2013) "Big Banks in Small Places: Are Community Banks Being Driven Out of Rural Markets?," Federal Reserve Bank of St. Louis Review, 95(3), 199-218.

Irwin, Michael, Charles M. Tolbert, and Thomas Lyson. (1999) "There's No Place Like Home: Nonmigration and Civic Engagement," Environment and Planning A, 31(12), 2223-2238.

Jayaratne, Jith and Philip E Strahan. (1998) "Entry restrictions, industry evolution, and dynamic efficiency: Evidence from commercial banking," The Journal of Law and Economics, 41(1), 239-274.

(C)Southern Regional Science Association 2020. 
Johnson, Shane A. and Salil K. Sarkar. (1996) "The Valuation Effects of the 1977 Community Reinvestment Act and Its Enforcement," Journal of Banking \& Finance, 20(5), 783-803.

Kandilov, Amy M. G. and Ivan T. Kandilov. (2017) "The Impact of Bank Branching Deregulations on the US Agricultural Sector," American Journal of Agricultural Economics, 100(1), 73-90.

Kashyap, Anil K. and Jeremy C. Stein. (2000) "What Do a Million Observations on Banks Say About the Transmission of Monetary Policy?," American Economic Review, 90(3), 407-428.

Kerr, William R. and Ramana Nanda. (2009) "Democratizing Entry: Banking Deregulations, Financing Constraints, and Entrepreneurship," Journal of Financial Economics, 94(1), 124-149.

Kilkenny, Maureen. (2002) "Community Credit," International Regional Science Review, $25(3), 247-251$.

Lee, Matthew R. (2008) "Civic Community in the Hinterland: Toward a Theory of Rural Social Structure and Violence," Criminology, 46(2), 447-478.

LeSage, James P. (2014) "What Regional Scientists Need to Know about Spatial Econometrics," Review of Regional Studies, 44(1), 13-32.

LeSage, James P. and Manfred M. Fischer. (2008) "Spatial Growth Regressions: Model Specification, Estimation and Interpretation," Spatial Economic Analysis, 3(3), 275-304.

LeSage, James P. and Robert Kelley Pace. (2009) Introduction to Spatial Econometrics. Chapman and Hall/CRC.

LeSage, James P. and Olivier Parent. (2007) "Bayesian Model Averaging for Spatial Econometric Models," Geographical Analysis, 39(3), 241-267.

Levine, Ross, Norman Loayza, and Thorsten Beck. (2002) "Financial Intermediation and Growth: Causality and Causes," Central Banking, Analysis, and Economic Policies, 3, 31-84.

Lobao, Linda, Minyu Zhou, Mark Partridge, and Michael Betz. (2016) "Poverty, Place, and Coal Employment Across Appalachia and the United States in a New Economic Era," Rural Sociology, 81(3), 343-386.

Markley, Deborah M. and Ron Shaffer. (1993) "Rural Banks and their Communities: A Matter of Survival," The Economic Review - Federal Reserve Bank of Kansas City, 78, $73-73$.

Mencken, F. Carson and Charles M. Tolbert. (2016) "Restructuring of the Financial Industry and Implications for Sources of Start-up Capital for New Businesses in Nonmetropolitan Counties," Journal of Rural Social Sciences, 31(1), 71-82.

Mencken, F. Carson and Charles M. Tolbert. (2018) "Locally Owned Bank Concentration and Bank Loans for Nonmetropolitan Business Start-Ups and Expansions: A Multilevel Analysis from the 2007 Survey of Business Owners," Rural Sociology, 83(2), 376-401.

Morgan, Donald P., Bertrand Rime, and Philip E. Strahan. (2004) "Bank Integration and State Business Cycles," The Quarterly Journal of Economics, 119(4), 1555-1584.

Partridge, Mark D. and Dan S. Rickman. (2006) The Geography of American Poverty: Is There a Need for Place-based Policies? W. E. Upjohn Institute for Employment Research. Kalamazoo, Michigan.

Peek, Joe and Eric Rosengren. (1995) "Bank Regulation and the Credit Crunch," Journal of Banking \&5 Finance, 19(3-4), 679-692.

(C)Southern Regional Science Association 2020. 
Petersen, Mitchell A. and Raghuram G. Rajan. (1994) "The Benefits of Lending Relationships: Evidence From Small Business Data," The Journal of Finance, 49(1), 3-37.

Rey, Sergio J. and Mark V. Janikas. (2005) "Regional Convergence, Inequality, and Space," Journal of Economic Geography, 5(2), 155-176.

Rey, Sergio J. and Brett D. Montouri. (1999) "US Regional Income Convergence: A Spatial Econometric Perspective," Regional Studies, 33(2), 143-156.

Rice, Tara and Jonathan Rose. (2016) "When Good Investments Go Bad: The Contraction in Community Bank Lending After the 2008 GSE Takeover," Journal of Financial Intermediation, 27, 68-88.

Rice, Tara and Philip E. Strahan. (2010) "Does Credit Competition affect Small-firm Finance?," The Journal of Finance, 65(3), 861-889.

Robb, Alicia M. and Robert W. Fairlie. (2007) "Access to Financial Capital Among US Businesses: The Case of African American Firms," The Annals of the American Academy of Political and Social Science, 613(1), 47-72.

Rupasingha, Anil, Stephan J. Goetz, and David Freshwater. (2002) "Social and Institutional Factors as Determinants of Economic Growth: Evidence from the United States Counties," Papers in Regional Science, 81(2), 139-155.

Rupasingha, Anil, Yongzheng Liu, and Mark Partridge. (2015) "Rural Bound: Determinants of Metro to Non-metro Migration in the United States," American Journal of Agricultural Economics, 97(3), 680-700.

Shaffer, Sherrill and Robert N. Collender. (2008) "Rural Economic Performance and Federal Credit Programs," Canberra, Australia: The Australian National University: Centre for Applied Macroeconomic Analysis Working Paper 26.

Strahan, Philip E. and James P. Weston. (1998) "Small Business Lending and the Changing Structure of the Banking Industry," Journal of Banking $\&$ Finance, 22(6-8), 821-845.

Tolbert, Charles M., Michael D. Irwin, Thomas A. Lyson, and Alfred R. Nucci. (2002) "Civic Community in Small-town America: How Civic Welfare is Influenced by Local Capitalism and Civic Engagement," Rural Sociology, 67(1), 90-113.

Tolbert, Charles M., Thomas A. Lyson, and Michael D. Irwin. (1998) "Local Capitalism, Civic Engagement, and Socioeconomic Well-being," Social Forces, 77(2), 401-427.

Tolbert, Charles M., F. Carson Mencken, T. Lynn Riggs, and Jing Li. (2014) "Restructuring of the Financial Industry: The Disappearance of Locally Owned Traditional Financial Services in Rural America," Rural Sociology, 79(3), 355-379.

Tolbert, Charles M. and Molly Sizer. (1996) "US Commuting Zones and Labor Market Areas: a 1990 Update (Staff Paper No. AGES-9614)," Washington, DC: US Department of Agriculture: Rural Economy Division, Economic Research Service.

Valdez, Zulema. (2011) The New Entrepreneurs: How Race, Class, and Gender Shape American Enterprise. Stanford University Press.

Vega, Solmaria Halleck and J. Paul Elhorst. (2015) "The SLX Model," Journal of Regional Science, 55(3), 339-363.

Vera, David and Kazuki Onji. (2010) "How Bank Consolidation is Good for Small Businesses," Small Business Economics, 34(3), 293-308.

Voss, Paul R., David D. Long, Roger B. Hammer, and Samantha Friedman. (2006) "County Child Poverty Rates in the US: A Spatial Regression Approach," Population Research and Policy Review, 25(4), 369-391.

(C)Southern Regional Science Association 2020. 
Walzer, Norman, Adee Athiyaman, and Gisele F. Hamm. (2007) "Entrepreneurship and Small Business Growth," In Walzer, Norman, ed., Entrepreneurship and Local Economic Development. Lexington Books: Lanham, MD, pp. 81-102.

Whaling, Christopher L. (1996) "Technological Innovation and the US Banking Industry: Innovation in the US Retail and Wholesale Banking Sectors," Technology in Society, 18(4), 477-501.

Wu, JunJie and Munisamy Gopinath. (2008) "What Causes Spatial Variations in Economic Development in the United States?," American Journal of Agricultural Economics, 90(2), 392-408.

(C)Southern Regional Science Association 2020. 


\section{APPENDIX}

Table A1: Panel Regressions with Decennial Establishment Births and

\begin{tabular}{|c|c|c|c|c|}
\hline \multicolumn{5}{|c|}{ Control Variables } \\
\hline & $(1)$ & $(2)$ & $(3)$ & $(4)$ \\
\hline & Birth Growth & Births & Future Births & Future \\
\hline & POLS & Growth FE & POLS & Births FE \\
\hline \multirow[t]{2}{*}{ Local ownership } & $-0.038 * * *$ & $-0.078 * * *$ & $-0.014^{* * *}$ & $-0.059 * * *$ \\
\hline & $(0.004)$ & $(0.010)$ & $(0.005)$ & $(0.007)$ \\
\hline \multirow[t]{2}{*}{ Local owned and micro } & $0.014^{* * *}$ & 0.005 & $0.015^{* *}$ & $0.016^{*}$ \\
\hline & $(0.005)$ & $(0.010)$ & $(0.006)$ & $(0.009)$ \\
\hline \multirow[t]{2}{*}{ Local owned and non-core } & $0.042^{* * *}$ & $0.076^{* * *}$ & $0.053^{* * *}$ & $0.099 * * *$ \\
\hline & $(0.005)$ & $(0.010)$ & $(0.005)$ & $(0.008)$ \\
\hline \multirow[t]{2}{*}{ Standardized population } & $0.187^{* * *}$ & $6.142^{* * *}$ & $-0.154^{* * *}$ & $6.238 * * *$ \\
\hline & $(0.049)$ & $(1.023)$ & $(0.047)$ & $(1.171)$ \\
\hline \multirow[t]{2}{*}{ Bachelor's degree percent } & $0.033^{* * *}$ & $0.447^{* * *}$ & -0.007 & $0.354^{* * *}$ \\
\hline & $(0.008)$ & $(0.072)$ & $(0.009)$ & $(0.0478)$ \\
\hline \multirow[t]{2}{*}{ Poverty percent } & $0.122^{* * *}$ & $0.357^{* * *}$ & $0.226^{* * *}$ & $0.406^{* * *}$ \\
\hline & $(0.019)$ & $(0.076)$ & $(0.019)$ & $(0.045)$ \\
\hline \multirow[t]{2}{*}{ Black percent } & 0.004 & $0.166^{* * *}$ & 0.002 & $0.087^{*}$ \\
\hline & $(0.004)$ & $(0.055)$ & $(0.006)$ & $(0.046)$ \\
\hline \multirow[t]{2}{*}{ Asian percent } & $-0.338 * * *$ & $-0.522^{* * *}$ & $-0.100 * * *$ & $-0.221^{* * *}$ \\
\hline & $(0.057)$ & $(0.097)$ & $(0.032)$ & $(0.055)$ \\
\hline \multirow[t]{2}{*}{ Hispanic percent } & $0.086^{* * *}$ & $0.152^{*}$ & $0.042^{* * *}$ & $-0.138^{* *}$ \\
\hline & $(0.015)$ & $(0.088)$ & $(0.014)$ & $(0.060)$ \\
\hline \multirow[t]{2}{*}{ Unemployment rate } & $-0.218^{* * *}$ & $-0.411^{* * *}$ & $-0.606^{* * *}$ & $-0.500 * * *$ \\
\hline & $(0.038)$ & $(0.084)$ & $(0.037)$ & $(0.053)$ \\
\hline \multirow[t]{2}{*}{ Micropolitan } & $-0.631^{* * *}$ & & $-0.935^{* * *}$ & \\
\hline & $(0.182)$ & & $(0.230)$ & \\
\hline \multirow[t]{2}{*}{ Non-core } & $-2.123^{* * *}$ & & $-1.866^{* * *}$ & \\
\hline & $(0.227)$ & & $(0.249)$ & \\
\hline \multirow[t]{2}{*}{ Constant } & $11.520 * * *$ & $3.555^{* *}$ & $20.530 * * *$ & $13.400 * * *$ \\
\hline & $(0.404)$ & $(1.477)$ & $(0.390)$ & $(1.021)$ \\
\hline Observations & 9,000 & 9,000 & 9,000 & 9,000 \\
\hline R-squared & 0.497 & 0.512 & 0.563 & 0.612 \\
\hline Year FE & YES & YES & YES & YES \\
\hline State FE & YES & & YES & \\
\hline
\end{tabular}

Notes: Robust standard errors in parentheses. ${ }^{* * * *} p<0.01,{ }^{* *} p<0.05,{ }^{*} p<0.1$

(c)Southern Regional Science Association 2020. 
Table A2: Panel Regressions with Decennial Establishment Deaths and Control Variables

\begin{tabular}{|c|c|c|c|c|}
\hline & $\begin{array}{c}(1) \\
\text { Deaths Growth } \\
\text { POLS }\end{array}$ & $\begin{array}{c}(2) \\
\text { Deaths } \\
\text { Growth FE }\end{array}$ & $\begin{array}{c}(3) \\
\text { Future Deaths } \\
\text { POLS }\end{array}$ & $\begin{array}{c}(4) \\
\text { Future } \\
\text { Deaths FE }\end{array}$ \\
\hline \multirow[t]{2}{*}{ Local ownership } & -0.000 & 0.006 & $0.003^{*}$ & $0.005^{* *}$ \\
\hline & $(0.002)$ & $(0.004)$ & $(0.002)$ & $(0.002)$ \\
\hline \multirow[t]{2}{*}{ Local owned and micro } & -0.001 & 0.001 & 0.001 & 0.003 \\
\hline & $(0.002)$ & $(0.005)$ & $(0.002)$ & $(0.003)$ \\
\hline \multirow{2}{*}{ Local owned and non-core } & -0.003 & -0.005 & -0.001 & -0.004 \\
\hline & $(0.002)$ & $(0.004)$ & $(0.002)$ & $(0.002)$ \\
\hline \multirow[t]{2}{*}{ Standardized population } & 0.007 & $-0.493^{* * *}$ & $0.144^{* * *}$ & $-0.280 * * *$ \\
\hline & $(0.015)$ & $(0.182)$ & $(0.044)$ & $(0.087)$ \\
\hline \multirow[t]{2}{*}{ Bachelor's degree percent } & $-0.006^{*}$ & $-0.097 * * *$ & $0.013^{* * *}$ & $-0.022^{*}$ \\
\hline & $(0.004)$ & $(0.023)$ & $(0.004)$ & $(0.013)$ \\
\hline \multirow[t]{2}{*}{ Poverty percent } & 0.006 & 0.031 & $-0.020 * * *$ & -0.019 \\
\hline & $(0.007)$ & $(0.021)$ & $(0.008)$ & $(0.013)$ \\
\hline \multirow[t]{2}{*}{ Black percent } & 0.001 & $-0.075 * * *$ & $-0.013^{* * *}$ & $-0.025^{*}$ \\
\hline & $(0.002)$ & $(0.024)$ & $(0.003)$ & $(0.013)$ \\
\hline \multirow[t]{2}{*}{ Asian percent } & $0.100^{* * *}$ & $0.139^{* * *}$ & 0.004 & $0.032^{* * *}$ \\
\hline & $(0.011)$ & $(0.018)$ & $(0.008)$ & $(0.010)$ \\
\hline \multirow[t]{2}{*}{ Hispanic percent } & $-0.028^{* * *}$ & $-0.057^{* *}$ & $-0.013^{* * *}$ & 0.009 \\
\hline & $(0.005)$ & $(0.024)$ & $(0.005)$ & $(0.014)$ \\
\hline \multirow[t]{2}{*}{ Unemployment rate } & $-0.037^{* *}$ & $-0.051^{*}$ & $0.109^{* * *}$ & $0.024^{*}$ \\
\hline & $(0.015)$ & $(0.026)$ & $(0.014)$ & $(0.015)$ \\
\hline \multirow[t]{2}{*}{ Micropolitan } & -0.107 & & $-0.440 * * *$ & \\
\hline & $(0.092)$ & & $(0.104)$ & \\
\hline \multirow[t]{2}{*}{ Non-core } & -0.020 & & $-0.417^{* * *}$ & \\
\hline & $(0.102)$ & & $(0.115)$ & \\
\hline \multirow[t]{2}{*}{ Constant } & $-2.970 * * *$ & $-1.840 * * *$ & $7.140^{* * *}$ & $7.763^{* * *}$ \\
\hline & $(0.152)$ & $(0.442)$ & $(0.163)$ & $(0.253)$ \\
\hline Observations & 9,000 & 9,000 & 9,000 & 9,000 \\
\hline R-squared & 0.361 & 0.388 & 0.302 & 0.215 \\
\hline Year FE & YES & YES & YES & YES \\
\hline State FE & YES & & YES & \\
\hline
\end{tabular}

Notes: Robust standard errors in parentheses. ${ }^{* * * *} p<0.01,{ }^{* *} p<0.05,{ }^{*} p<0.1$

(c)Southern Regional Science Association 2020. 